\title{
Detailed site survey examining the postglacial sediment succession and depositional processes within a Norwegian fjord system, Biørnafjorden (West Norway)
}

\author{
Kenneth Solli', Jarle André Vikebø', Elise Søyland', Berit Oline Hielstuen², \\ Heidi Kjennbakken ${ }^{3} \&$ Tore Thomassen ${ }^{3}$
}

\author{
${ }^{1}$ DOF Subsea Norway AS, Thormøhlens Gate 53C, 5006 Bergen, Norway. \\ ${ }^{2}$ Department of Earth Science, University of Bergen, Allégt 41, 5007 Bergen, Norway. \\ ${ }^{3}$ Statens vegvesen Region vest, Askedalen 4, 6863 Leikanger, Norway. \\ E-mail corresponding author (Kenneth Solli): Kenneth.Solli@dofsubsea.com
}

\begin{abstract}
Based on a recently acquired dense grid of sub-bottom profiles and ultra-high resolution bathymetry, we have studied the postglacial depositional history of a West Norwegian fjord system. This dataset reveals a history of frequent mass failures taking place from all slopes surrounding the main studied sediment basin. The study also shows that present-day conditions may be subject to future mass wasting, as significant sediment volumes are retained on the basin margins. The overall sediment distribution seems to be largely governed by the underlying bedrock morphologies. Earthquakes are considered to represent the most dominant trigger mechanism in the area.
\end{abstract}

Keywords: Fjords, sedimentary processes, sediment distribution, gravity flows

Received 10. March 2017 / Accepted 26. May 2017 / Published online 26. June 2017

\section{Introduction}

The fjord systems situated along the west coast of Norway (Fig. 1A) represent topographic sediment traps that hold important information with regard to the postglacial depositional history. Nearly all sediments presently contained within western Norwegian fjords are considered to have been deposited during the deglaciation of the last (Weichselian) ice sheet (Aarseth, 1997). Mass gravity flows represent important processes within such systems and may have originated in both subaerial and submarine settings. The nature, dimension and frequency of such sediment gravity flows can vary significantly between the different fjord systems (Bøe et al., 2003; Hjelstuen et al., 2009, 2013; Bellwald et al., 2016), representing significant geohazards to both infrastructure and populated regions.
In this study, the fjord basin of the outer Bjørnafjord (Fig. 1A) has been examined in detail using a dense grid of recently acquired MBE (Multi-Beam Echosounder) and SBP (Sub-Bottom Profile) survey lines (Fig. 1B). The survey was conducted during the spring and autumn of 2016 by DOF Subsea Norway AS on behalf of the Norwegian public road administration and resulted in the generation of a database containing approximately 770 kilometres of survey data (Fig. 1B). The acquired data density in this area offers a unique opportunity for detailed studies of the depositional patterns within a fjord setting. For this particular study the objectives of the analyses have been fourfold; (1) identify main depositional processes, (2) establish a chronology for the deposited sediments, (3) determine the amount of sediments present and their distribution, and (4) suggest a trigger mechanism for the identified mass failures. 
The investigations were initiated as a consequence of a planned infrastructure (bridge) soon to be built, which required detailed knowledge about the local seabed conditions and overall sediment stability.

\section{Geological setting}

The Bjørnafjord is situated on the west coast of Norway, approximately $30 \mathrm{~km}$ south of Bergen (Fig. 1A). It represents a relatively wide and atypical fjord with undulating seabed bathymetry and several sediment basins. The study site is situated in the outer part of the fjord system where the bathymetry appears to be strongly dictated by the bedrock of the Major Bergen Arc system and its pronounced foliation and metamorphic layering (Kolderup \& Kolderup, 1940; Wennberg \& Milnes, 1994). Both on the northern and the southern flanks of the main fjord basin there are inclining plateaus of shallower ground (Figs. 2B \& 3). The terrain can be described as rough and water depths change dramatically over even short distances. The bathymetry varies from minimum depths of $7 \mathrm{~m}$ in the northeastern part of the study area to maximum depths of about $565 \mathrm{~m}$ within the main basin.

The seismic activity in western Norway is relatively high (Ahjos \& Uski, 1992). For Norway and adjacent areas the recurrence interval of a M5 earthquake is estimated to 10 years, while a M7 earthquake is suggested to occur every 1100 years (Bungum et al., 2005). The seismic activity is largely attributed to isostatic rebound after the last glacial maximum (LGM) and the retreat of the Fennoscandian Ice Sheet (FIS) (Byrkjeland et al., 2000). The outer Bjørnafjord is considered to have been ice-free since the Early Allerød, about 13.5 cal ka BP, with a readvance of the ice margin to the inner parts of the fjord during the Younger Dryas Chronozone (Aarseth et al., 1997; Mangerud et al., 2016). The further deglaciation, which took place from around $11.6 \mathrm{cal} \mathrm{ka} \mathrm{BP}$, is considered to have been very rapid with the ice front located at the head of the major fjords of western Norway only a few hundred years later (Aarseth et al., 1975).

\section{Data and methods}

The bathymetry of the survey area, with its highly undulating terrain, represents a challenging site in terms of collecting data. Consequently, the dataset was acquired using a combination of vessel-based systems and ROV (Remotely Operated Vehicle)-based systems. In general, the deep-water sections and the areas with difficult bathymetry have been surveyed with MV Geosund's ROV while the shallow-water areas and areas close to obstructions have been surveyed with the smaller survey vessel MV Geocat. Roughly $90 \%$ of the survey data has been acquired with the use of the ROV. In order to achieve the desired mapping of the seafloor, MV Geocat was fitted with a Kongsberg EM710 system (MBE) and an Innomar Deep (SBP, 1-10 kHz) system. The ROV was fitted with the R2Sonic 2024 (MBE) system, Innomar SES-2000 ROV (SBP primary, 4-22 kHz) and Edgetech 2200-M (SBP secondary, 1-15 kHz). The survey lines are mainly oriented $\mathrm{N}-\mathrm{S}$ and $\mathrm{E}-\mathrm{W}$ with an internal spacing of $50 \mathrm{~m}$ (Fig. 1B). Some additional lines have been surveyed in order to improve the MBE resolution of certain localities or to better capture the shallow geology of identified bathymetric features. The ROV platformed systems provided seismic penetrations down to about 50-60 metres, while the vessel based system yielded more than 80 metres of penetration.

The MBE data have been processed by the use of EIVAs software solutions and gridded to a spatial resolution of $0.5 \mathrm{~m} \times 0.5 \mathrm{~m}$. The identified sediment failures in the bathymetric data were mapped in terms of area of origin and area of deposition. The thickness map (isopach) is generated with the software GeoCap and presented with a spatial resolution of $5 \mathrm{~m} \times 5 \mathrm{~m}$ (Fig. 2A). Delph iXblue was used for the processing and analyses of the acquired sub-bottom data, that provided vertical resolutions down to about $10 \mathrm{~cm}$. For conversion to sediment thicknesses and depths in metres, a velocity of $1500 \mathrm{~ms} \otimes^{1}$ has been applied throughout the study. This is in line with other studies of similar deposits from western Norwegian fjords (Hjelstuen et al., 2013; Bellwald et al., 2016). The seismic data were interpreted based on changes in seismic facies.

\section{Observations and results}

The shallow geology of the Bjørnafjord area has been analysed on the basis of the observed seismic character, and two main units, Unit 1 (older) and Unit 2, are identified (Table 1).

Unit 1 is acoustically non-structural. Some chaotic internal character is observed locally in its upper part. The upper boundary of the unit is characterised by an irregular to highly irregular reflector. Unit 1 crops out on the seabed on some of the steepest sections, in slide scars and in nearshore areas. The top of this unit is defined as acoustic basement and it is considered to reflect bedrock (Figs. 4, 5 \& 6), although it cannot be excluded that locally it may also correspond to till material.

Unit 2 comprises a number of different seismic facies where the main ones are: (a) A thick and transparent sedimentary unit overlying Unit 1, locally also showing a weak internal lamination. This transparent facies can be traced across more or less the entire study area, being thickest within the basins and slightly thinner on the slopes. (b) Well-stratified patterns of high- to lowamplitude reflectors, commonly seen to be draping sub- 

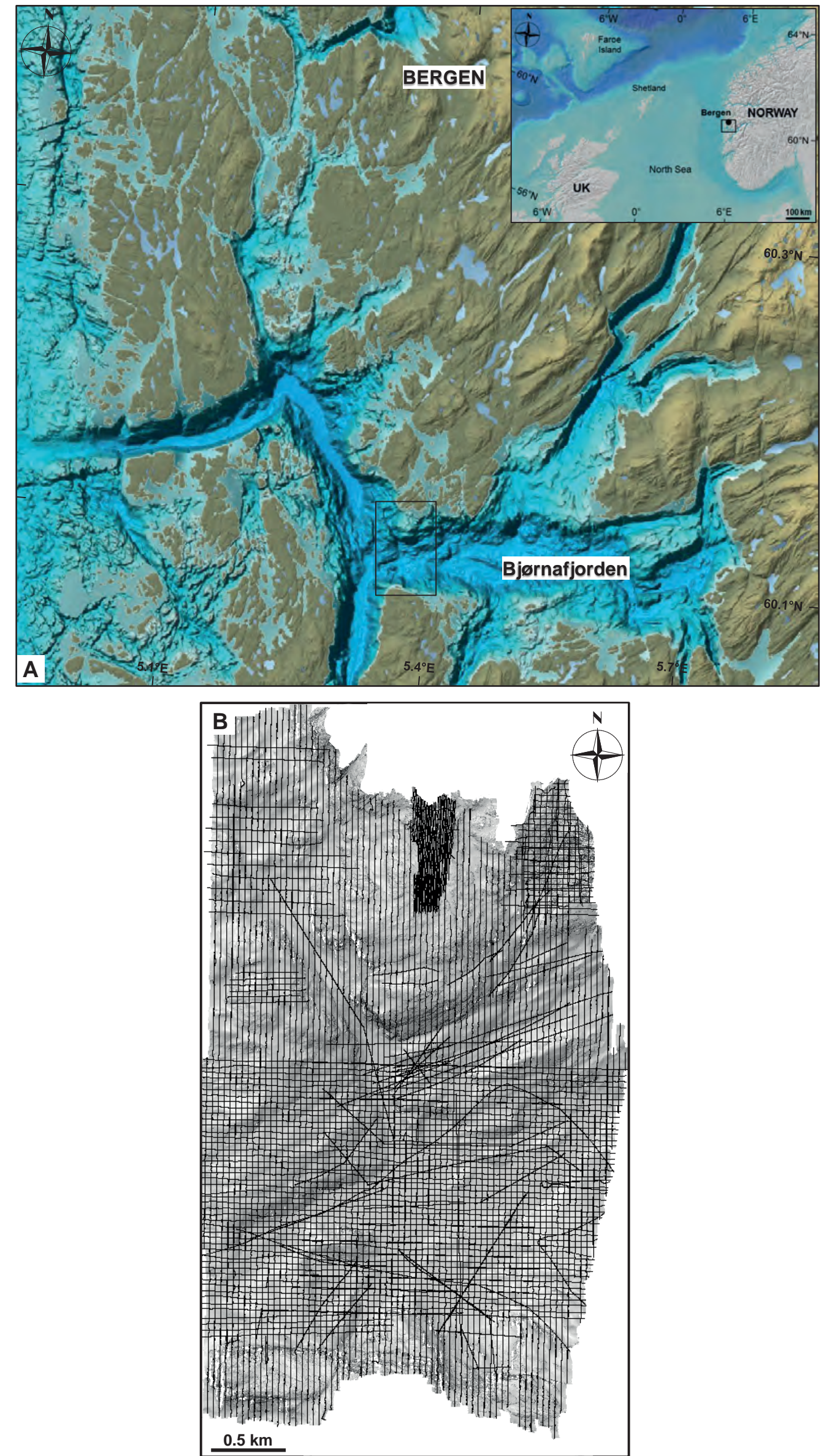

Figure 1. (A) Regional map showing the location of the study area; (B) Shaded relief image showing the locations of the acquired survey lines. Both SBP and MBE data have been acquired on all survey lines. 


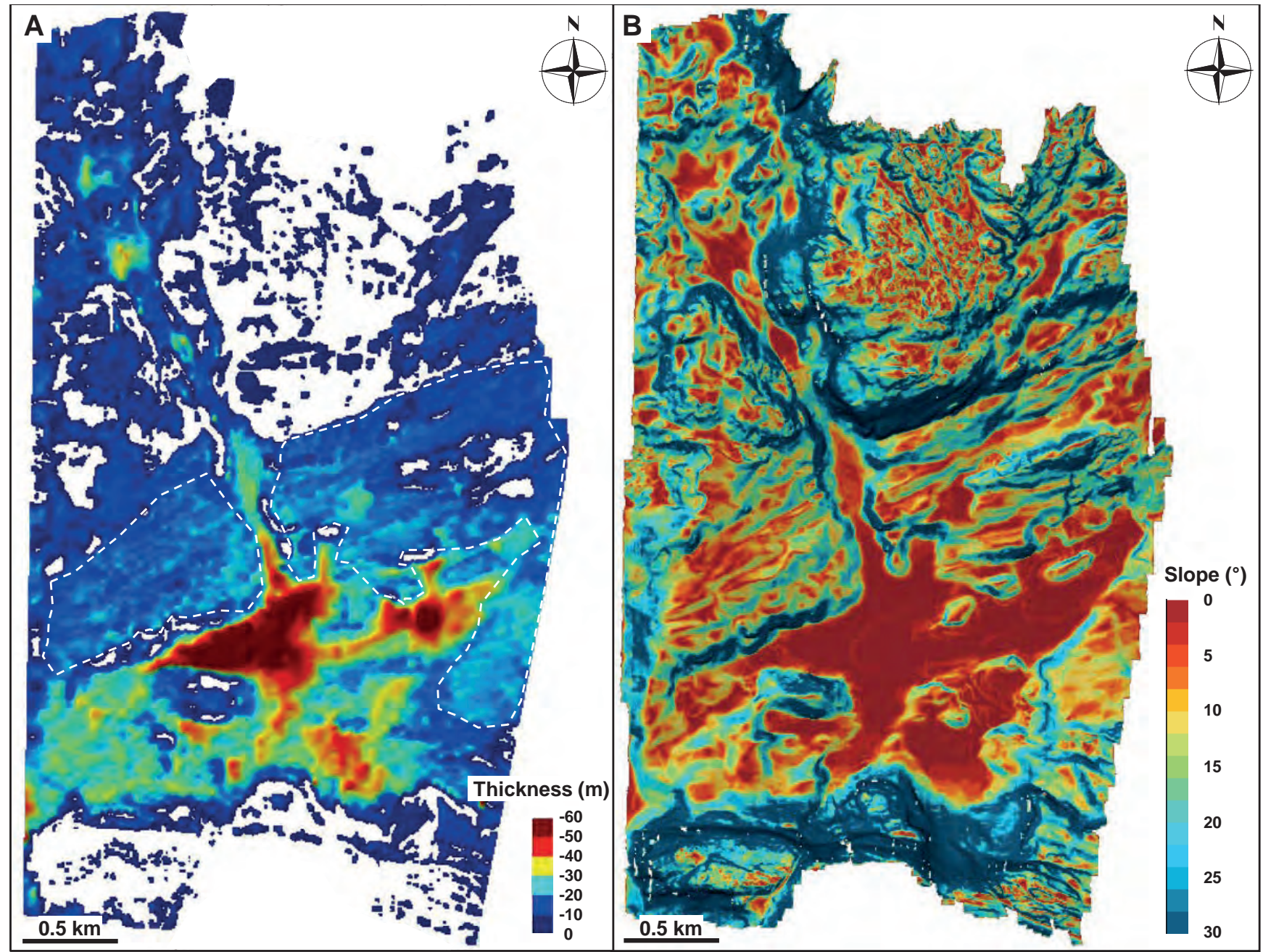

Figure 2. (A) Isopach map of Unit 2, illustrating the sediment thickness and sediment distribution within the study area. Dashed white lines highlight inclining plateaus still holding significant sediment accumulations; (B) Slope gradient map.

unit a. The upper parts of sub-unit b are characterised by a distinct band of high-reflectivity reflectors that can be traced over large parts of the study area. Only weak indications of erosion can be identified along the top of this unit. (c) Acoustically transparent lens-shaped units of variable size, and (d) elongated units with acoustically transparent to weakly laminated internal character (Figs. $4,5 \& 6)$. The acoustic sub-units $c$ and d appear to be laterally restricted to the basins and the lower parts of topographic inclinations.
The thickness and distribution of the postglacial sediment succession is illustrated in the produced isopach map (Fig. 2A), which is based on Unit 2 . Maximum thicknesses of almost $80 \mathrm{~m}$ are observed in the deepest part of the main basin, although the scale in Fig. 2A is limited to $60 \mathrm{~m}$ in order to provide more detail on the slope deposits. On the bathymetric slopes there are still significant amounts of sediments preserved showing thicknesses up to $20-30 \mathrm{~m}$, whereas the shallowest areas on both sides of the fjord reveal sediment accumulations

Table 1. Characteristics of identified seismic units in Bjørnafjorden.

\begin{tabular}{cll}
\hline Unit & Thickness & \multicolumn{1}{c}{ Seismic description } \\
\hline $\mathbf{2}$ & Max: $\sim 80 \mathrm{~m}$ & $\begin{array}{l}\text { Acoustically transparent unit with little or no internal lamination overlying acoustic basement } \\
\text { (seismic facies a). Well stratified patterns of high- to low-amplitude reflectors (seismic facies b). } \\
\text { Stacked, acoustically transparent lens-shaped units (seismic facies c). } \\
\text { Elongated, acoustically transparent facies, with occasional low-amplitude internal reflectors (seis- } \\
\text { mic facies d). }\end{array}$ \\
\hline $\mathbf{1}$ & N/A & $\begin{array}{l}\text { Acoustically non-structural. The top is marked by an irregular and undulating strong reflector. } \\
\text { Chaotic internal character in upper part, but little or no seismic penetration beneath the irregular } \\
\text { top reflector. }\end{array}$ \\
\hline
\end{tabular}




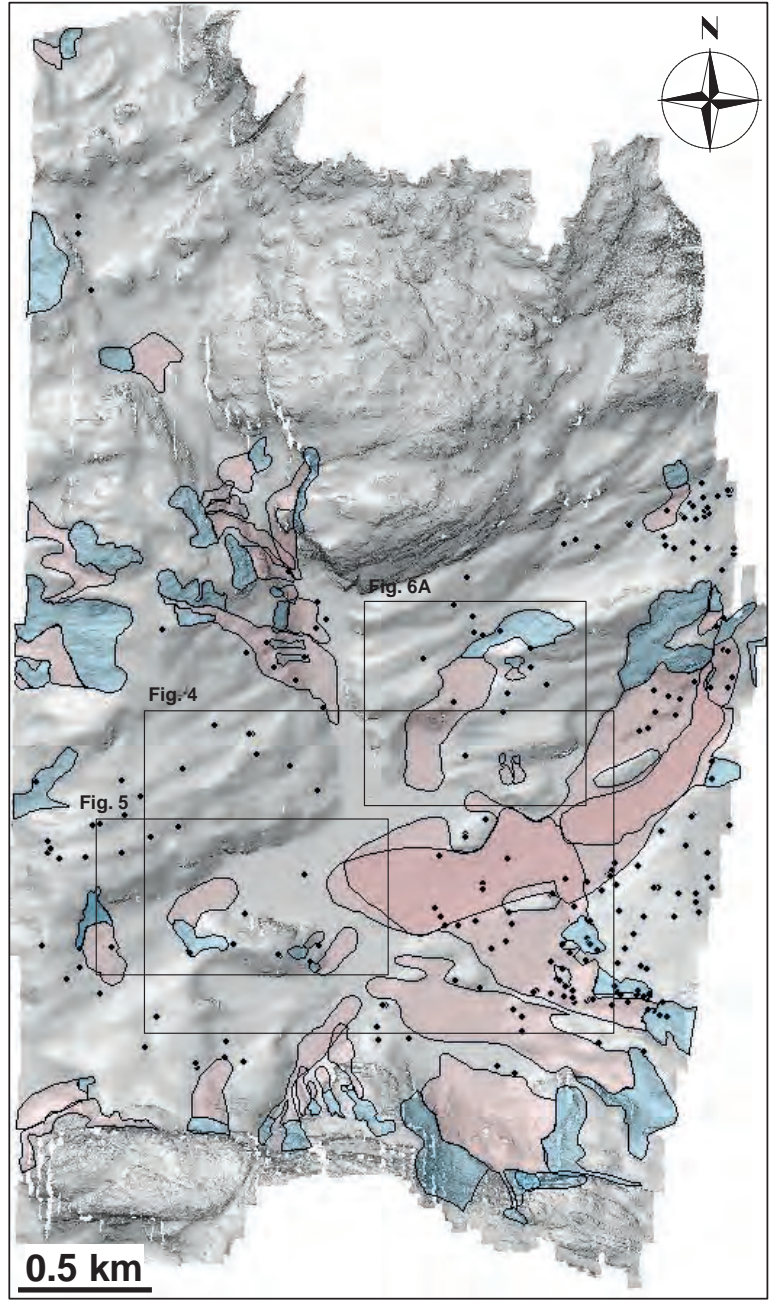

Figure 3. Shaded relief image of the survey area with mapped mass failures identifiable from the surface model. The failures are mapped in terms of area of origin (blue) and area of deposition (pink). The black dots mark the positions of the observed circular depressions. that are generally in the order of $<5 \mathrm{~m}$ thick. The overall sediment distribution is strongly linked to the morphology of the terrain and is hence presented alongside a slope gradient map (Fig. 2B). In general, it is observed that slopes with higher gradients are associated with more sediment starved areas and that slopes at similar water depths hold sediment accumulations of similar thicknesses.

The seabed along all flanks of the main Bjørnafjorden basin is also perforated by more than 200 circular depressions (Fig. 3). These features are typically between 6 and $8 \mathrm{~m}$ in diameter and approximately $0.2-0.3 \mathrm{~m}$ deep. The largest depression observed is located in the south-eastern corner of the main basin, measuring approximately $38.0 \mathrm{~m}$ x $1.8 \mathrm{~m} \mathrm{x} 38.0 \mathrm{~m} \mathrm{(1 \times} \mathrm{d} \mathrm{x} \mathrm{w).} \mathrm{The}$ majority of these concave seabed features are observed along the eastern flank of the main basin.

\section{Discussion}

\section{Sedimentary processes and chronology}

The examined sediment succession in Bjørnafjorden is considered to have been deposited during and after the retreat of the FIS. The seismic stratigraphy and patterns observed within the survey area are comparable to those observed within other western Norwegian fjords where similar seismic data have been analysed (Hjelstuen et al., 2009, 2013; Hjelstuen \& Brendryen, 2014; Bellwald et al., 2016). In the lowermost part of Unit 2 (sub-units $\mathrm{a}$ and $\mathrm{b}$ ) the deposits form a relatively thick, acoustically well laminated sequence with parallel to subparallel reflectors (Figs. 4, $5 \& 6$ ) that become more transparent towards the base. This initial part of the sedimentation history is considered to reflect a stage of ice-proximal deposition in which the fjords acted as local sediment traps. We interpret these seismic facies to represent

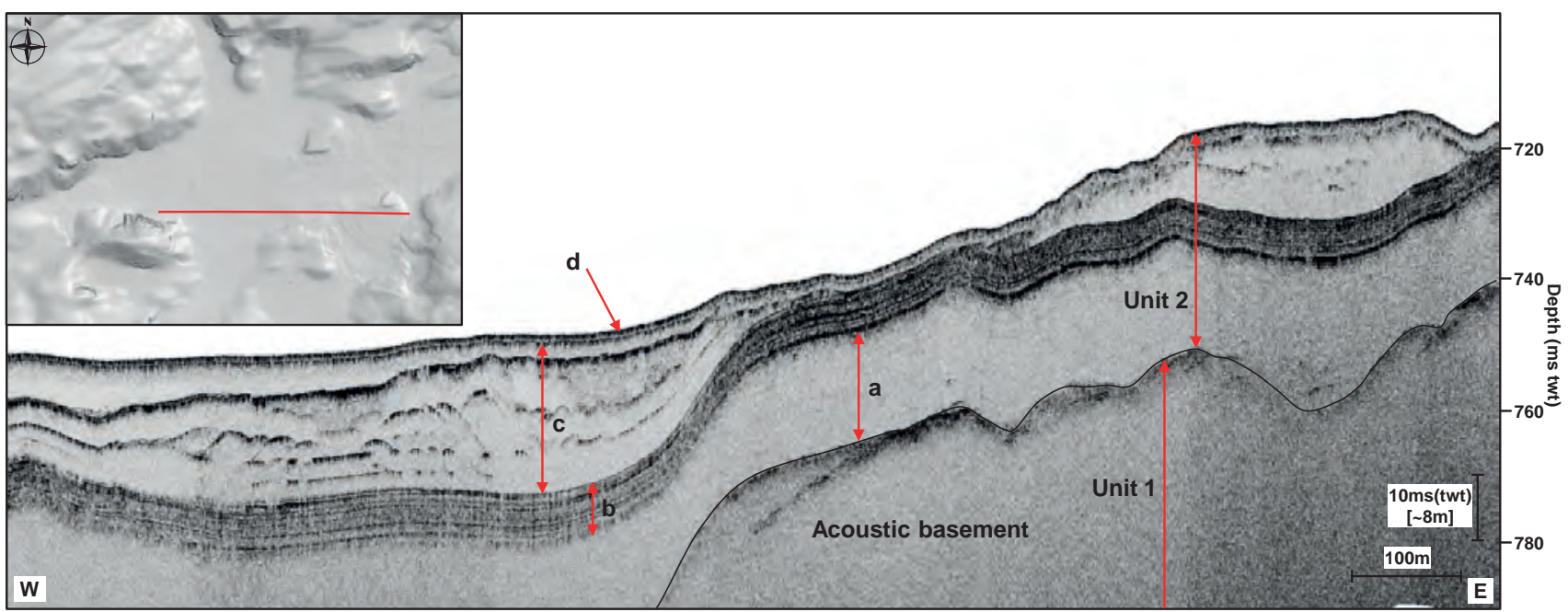

Figure 4. SBP profile from the central part of Bjørnafjord illustrating the different seismic facies $(a-d)$ that have been identified. Insert showing the location of the SBP survey line with regard to the produced terrain model. 


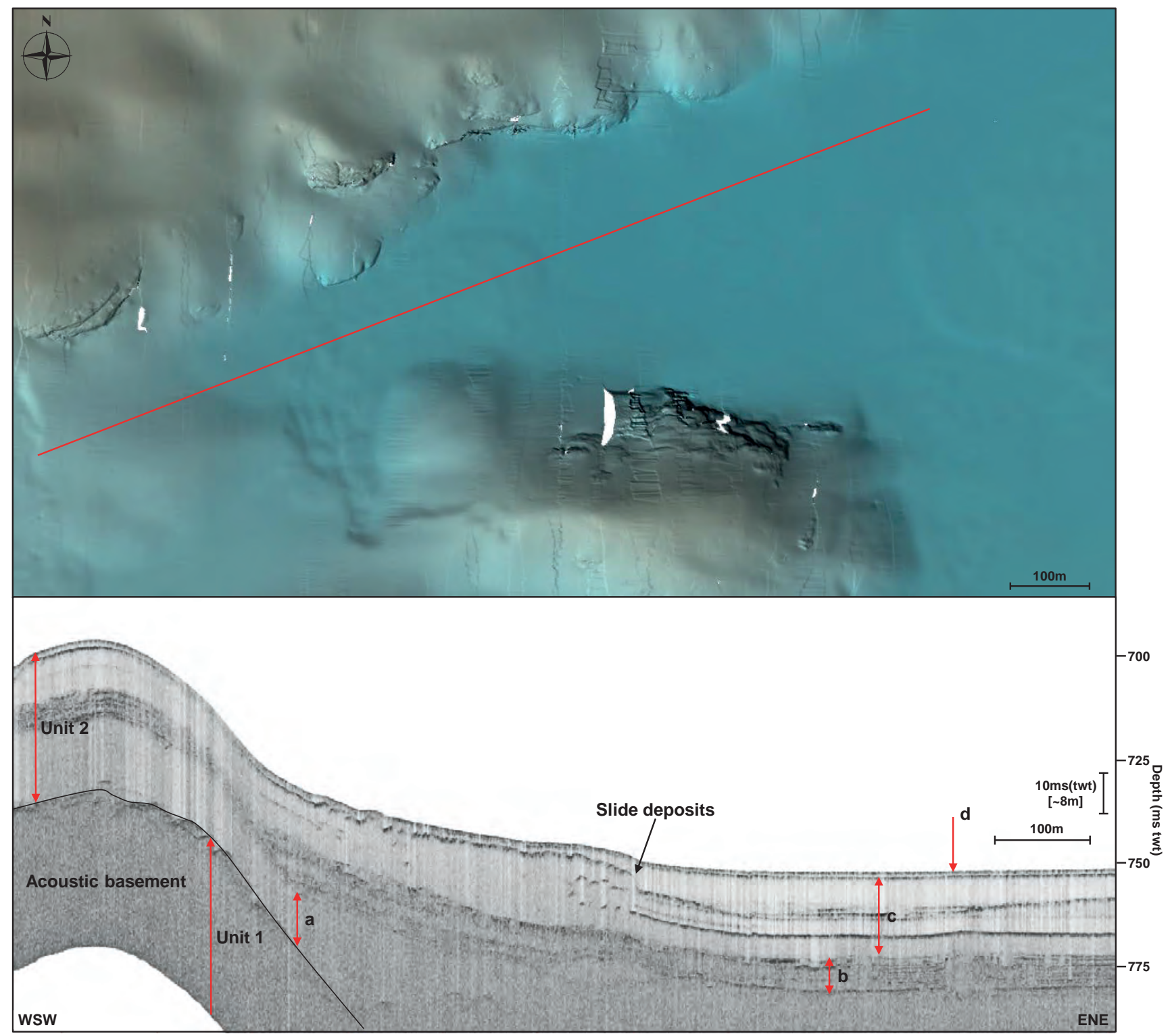

Figure 5. Upper Panel: MBE data example with location of SBP line displayed. Lower Panel: SBP data example from the western side of the survey area showing the character of the identified seismic facies $(a-d)$. One of the slides mapped is annotated. The upslope scars of this slide are apparent in the MBE data where the SBP profile crosses over the downslope slide accumulation (see also Figure 3).

glacimarine and/or hemipelagic sedimentation (Stoker et al., 2006; Hjelstuen et al., 2009, 2013; Lyså et al., 2010). The glacimarine deposits are overlain by lens-shaped acoustically transparent deposits (Figs. 4, 5 \& 6). The lens-shaped units range in scale from small features tens of metres wide and up to one metre thick, to much largerscale features that extend over several hundred metres and show thicknesses up to about $10 \mathrm{~m}$. The largest feature detected in the surface model is propagating into the main basin from the east (see Fig. 3) and the front of this tongue is also apparent in the slope gradient map (Fig. 2B). These stacked, lens shaped deposits are considered to represent slide debrites (Hjelstuen et al., 2009, 2013). The lack of erosional features associated with the deposition of these slide deposits, might suggest that they consist predominantly of very soft sediments.
The evidence for these mass failures is seen from both the multi-beam data and the sub-bottom profiler data (Figs. $4,5 \& 6)$. Within the uppermost part of the slide zones, the entire sediment succession down to the acoustic basement appears to be incorporated in the slides (Fig. 6). Their associated seabed scars are widespread around the flanks of the main basin and along the sides of the gorge-like feature extending from the main basin to the northwestern corner of the study area. More than 45 individual mass failures have been identified and mapped from the surface model alone (Fig. 3). The head and side walls of the sediment gravity flows mark their outer limits on the upslope part of the seafloor, while elongated features with positive reliefs are manifested on the downslope end and indicate the extent of the propagation. The sediment gravity flows appear to have 
been initiated mainly from localities that reveal surface slopes in the order of $\sim 20^{\circ}$ or more. In some parts of the study area there are also indications of cross-cutting and/or overlapping gravity flows (Fig. 3). There are no indications of internal glide planes within Unit 2.

The observed change in the sedimentary patterns may suggest that the initial deglaciation was followed by a stage of rapid glaci-isostatic adjustments (e.g., Bøe et al., 2004; Lyså et al., 2010) that gave rise to a new depositional regime within the fjord system, in which unstable sediments on the slopes were frequently mobilised and redeposited. Estimates from other nearby fjord studies showing a similar depositional development suggest that the shift is associated with the rapid deglaciation taking place after Younger Dryas (Hjelstuen et al., 2009, 2013; Bellwald et al., 2016). At the stratigraphic top, the deposits are commonly seen to be draped by a thin regional unit that shows little variation in thickness. This unit is most often found to be acoustically transparent (Facies $\mathrm{d}$ in Figs. 4, 5 \& 6), but can also contain some weak internal laminations. We interpret these sediments to have been derived predominantly by hemipelagic deposition, but also with contributions from various occasional mass gravity flows.

\section{Sediment distribution and trigger mechanisms}

The produced isopach map (Fig. 2A) suggests that the postglacial supply of sediments to the flanks of the main Bjørnafjord basin has been relatively uniform. There are no clear indications of any distinct historical depocentres. This is further supported by the observation of sediment gravity flows taking place from all sides of the main basin (Fig. 3), and not being restricted to any particular section. The most recent gravity flows that are recognisable from the surface model and the SBP data may, however, indicate a somewhat higher contribution of input from the eastern slopes towards the main basin. From the thickness map (Fig. 2A) it is also clear that significant sediment volumes are still retained on the basin slopes, especially on the northern and eastern sides. These deposits must also be considered as relatively unstable. They share the same origin and have similar topographical constraints as already mass-wasted deposits, and it is hence likely that they will be subjected to future mass wasting. It is, however, difficult to make any assumptions about when and where such failures are going to take place.

Western Norway represents one of the most seismically active areas in Scandinavia (Ahjos \& Uski, 1992; Bungum et al., 2005) and it is hence likely that earthquakes could have acted as the main trigger mechanism for such mass failures, as seen for other fjords along the Westand Mid-Norwegian coastline (Bøe et al., 2004). Other potential trigger mechanisms such as climate change and tsunami induced destabilisations are known to have affected the region under specific time periods (Hjelstuen et al., 2014), although it remains to be verified with geotechnical information whether or not this also influenced the deposition within Bjørnafjorden.

The numerous circular depressions observed in and around the areas of mass wasting may, however, also indicate that there are other factors influencing and facilitating these failures. We interpret these depressions as pockmarks and the formation of such pockmarks is mostly caused by the seepage of thermogenic and biogenic gases (Rogers et al., 2006) and the release of pore water (Harrington, 1985). Such fluid-escape features and their associated fluid movements within the sediments might have lessened the overall stability of the deposits and hence contributed to setting some of these mass failures in motion, as also suggested by Bellwald et al. (2016). It should be noted that pockmarks and associated shallow gas emissions have been observed in fjords on Svalbard (Baeten et al., 2010; Forwick et al., 2010), in Scottish fjords (Stoker et al., 2006) and in fjords in northern Norway (Plassen \& Vorren, 2003; Morgan et al., 2010). The importance and influence of these features in relation to the mass wasting remain, however, questionable due to two significant observations. They are not only spatially restricted to the areas subjected to mass wasting, and the analysed sediment failures are mostly seen to affect the entire sediment succession down to the acoustic basement. Also, it cannot be excluded that some of the smaller depressions might correspond to point targets on the seabed that have been subjected to localised circumferential erosion, either through fish activity (e.g., Muniz et al., 2015) or bottom currents.

The data from Bjørnafjorden suggest that oversteepening is not a dominant trigger mechanism in this area. We have not observed any clear signs of focused sediment supply to the surrounding basin margins nor evidence of erosion from contour-parallel currents, which also could have influenced the slope stability.

Keeping the observations and results from this study in mind, the primary focus should be on slope angles for risk assessment with regard to future mass wasting. 


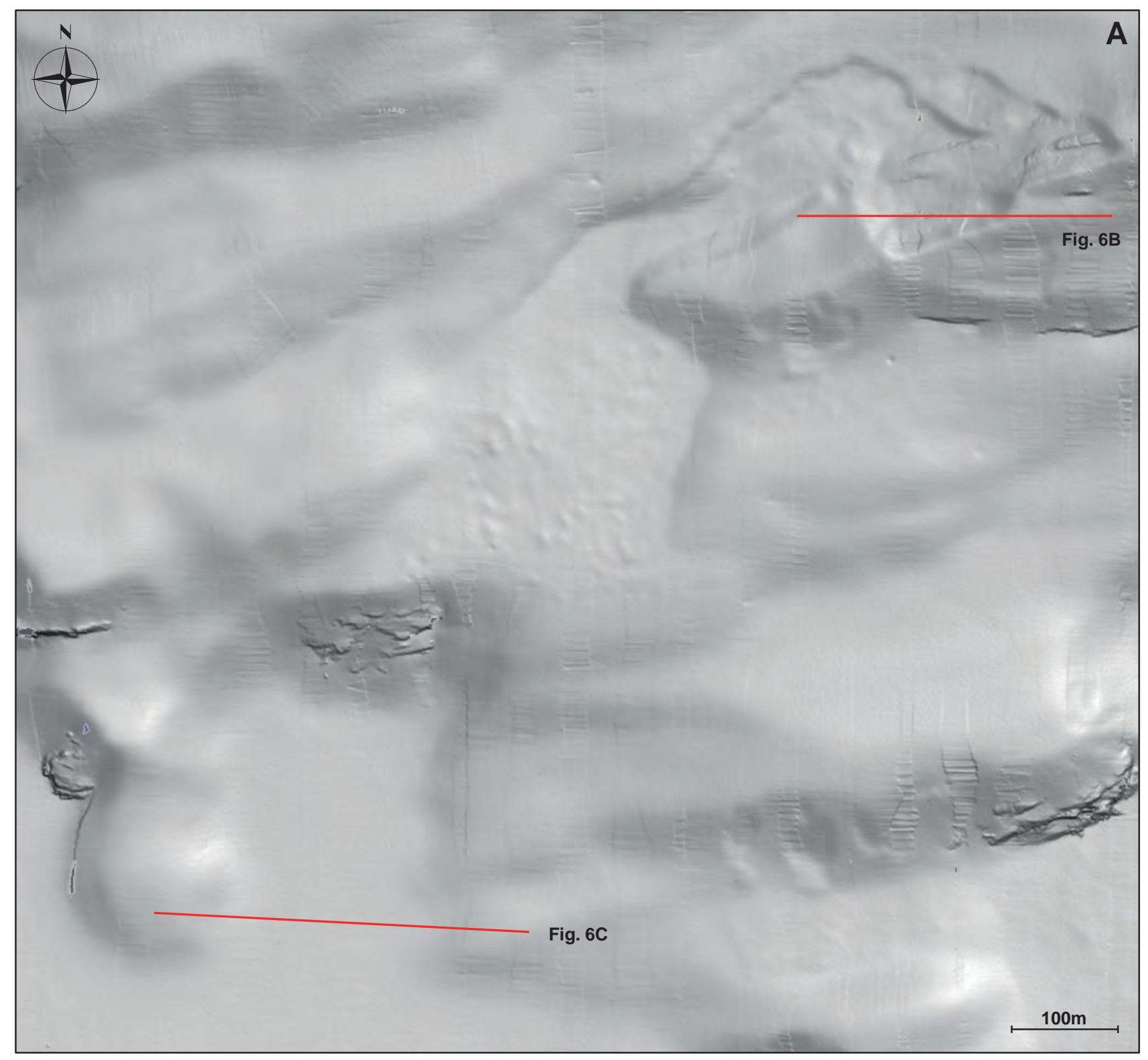

Figure 6. (A) Detailed shaded relief image showing the positions of SBP lines illustrated in Figs. $6 B$ \& $6 C$ with regard to the exposed slide.

\section{Conclusions}

We have studied sedimentary processes and the postglacial depositional history within a western Norwegian fjord system, by utilising recently collected ultra-high resolution MBE data and SBP profiles. This study shows that:

- Bjørnafjorden contains an up to $80 \mathrm{~m}$-thick sediment package deposited during and after the withdrawal of the LGM ice sheet. The sediment distribution is to a large extent governed by the relief of the underlying bedrock.

- The slopes of the main basin appear to have been supplied with relatively uniform amounts of sediment, as no distinct depocentres are recognised.
- The lower glacimarine unit is covered by a sequence of stacked slide debrites which reach individual maximum thicknesses of approximately $10 \mathrm{~m}$. These slide debrites are commonly draped by a thin layer of hemipelagic sediments.

- Sediment gravity flows are seen to have taken place from all sides of the main basin and there are still significant amounts of potentially unstable deposits retained on the surrounding slopes.

- Earthquakes are considered to represent the most dominant trigger mechanism for the sediment gravity flows within Bjørnafjorden. 

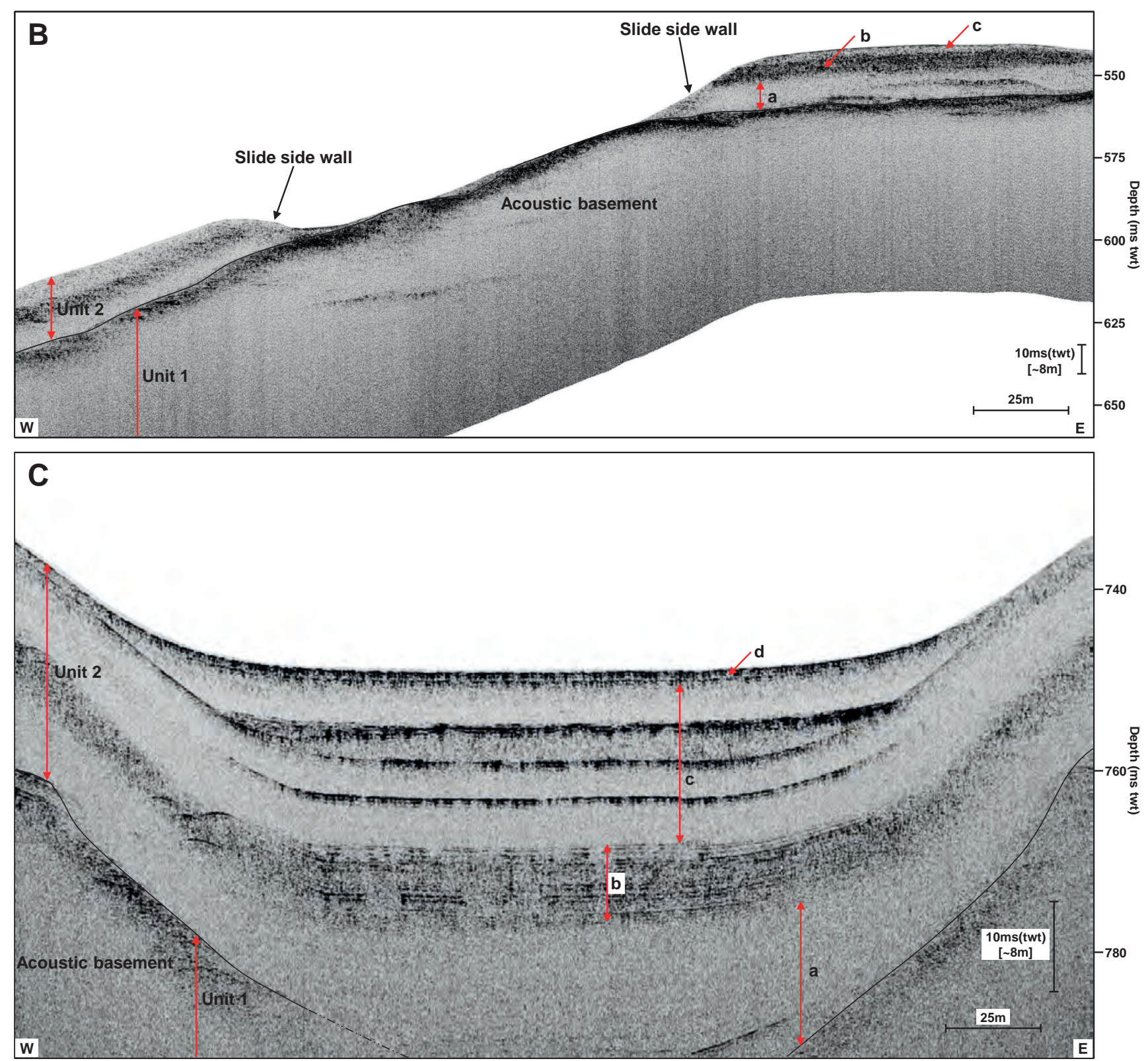

Figure 6. (Continued) (B) SBP profile crossing the uppermost parts of the slide; (C) SBP profile crossing the downslope part of the slide.

The analyses and results of this study indicate a history of deposition within Bjørnafjorden that is consistent with observations from other nearby West Norwegian fjord systems. The time span for these developments is therefore also considered to be relatively similar, although this remains to be confirmed by ground truthing. The data show that sediment gravity flows represent the most significant depositional process within the fjord and are also likely to remain so in the future. Potential mass failures therefore constitute a challenge that needs to be carefully assessed in any planned infrastructural development along this sector of the West Norwegian coastline.
Acknowledgements. We acknowledge the personnel and crew on board MV Geosund and MV Geocat for all their efforts in the collection of the data. Thanks to the Norwegian public road administration for allowing us to publish some of the results from the analyses of this dataset. We are grateful for the insightful reviews provided by Leif Rise and an anonymous reviewer. 


\section{References}

Aarseth, I. 1997: Western Norwegian fjord sediments: age, volume, stratigraphy, and role as temporary depository during glacial cycles. Marine Geology 143, 39-53. https://doi.org/10.1016/S0025-3227(97)00089-3.

Aarseth, I., Bjerkeli, K., Bjorklund, K.R., Boe, D., Holm, J.P., LorentzenStyr, T.J., Myhre, L.A., Ugland, E.S. \& Thiede, J. 1975: Late Quarternary sediments from Korsfjorden, Western Norway. Sarsia 58, 43-66. https://doi.org/10.1080/00364827.1975.10411278.

Aarseth, I., Austbø, P.K. \& Risnes, H. 1997: Seismic stratigraphy of Younger Dryas ice-marginal deposits in Western Norwegian fjords. Norwegian Journal of Geology 77, 65-85.

Ahjos, T. \& Uski, M. 1992: Earthquakes in northern Europe in 13751989. Tectonophysics 207, 1-23. https://doi.org/10.1016/0040-1951(92)90469-M.

Baeten, N.J., Forwick M., Vogt, C. \& Vorren, T.O. 2010: Late Weichselian and Holocene sedimentary environments and glacial activity in Billefjorden, Svalbard. In Howe, J.A., Austin, W.E.N., Forwick, M. \& Paetzel, M. (eds.): Fjord systems and archives, Geological Society Special Publication 344: London, pp. 207-233.

https://doi.org/10.1144/sp344.15.

Bellwald, B., Hjelstuen, B.O., Sejrup, H.P. \& Haflidason, H. 2016: Postglacial Mass Failures in the Inner Hardangerfjorden System, Western Norway. In Lamarche G et al., (eds.): Submarine mass movements and their Consequenses, Advances in Natural and Technological Hazards Research 41, pp. 73-82. https://doi.org/10.1007/978-3-319-20979-1_7.

Bungum, H., Lindholm, C. \& Faleide, J.I. 2005: Postglacial seismicity offshore mid-Norway with emphasis on spatio-temporalmagnitudal variations. Marine and Petroleum Geology 22, 137-148. https://doi.org/10.1016/j.marpetgeo.2004.10.007.

Byrkjeland, U., Bungum, H. \& Eldholm, O. 2000: Seismotectonics of the Norwegian continental margin. Journal of Geophysical Research 105, 6221-6236. https://doi.org/10.1029/1999JB900275.

Bøe, R., Rise, L., Blikra, L.H., Longva, O. \& Eide, A. 2003: Holocene mass-movement processes in Trondhjemsfjorden, Central Norway. Norwegian Journal of Geology 83, 3-22.

Bøe, R., Longva, O., Lepland, A., Blikra, L.H., Sønstegaard, E., Haflidason, H., Bryn, P. \& Lien, R. 2004: Postglacial mass movements and their causes in fjords and lakes in western Norway. Norwegian Journal of Geology 84, 35-55.

Forwick, M., Vorren, T.O., Hald, M., Korsun, S. Roh, Y., Vogt, C. \& Yoo, K.-C. 2010: Spatial and temporal influence of glaciers and rivers on the sedimentary environment in Sassenfjorden and Tempelfjorden, Spitsbergen. In Howe, J.A., Austin, W.E.N., Forwick, M. \& Paetzel, M. (eds.): Fjord systems and archives, Geological Society: London Special Publication 344, pp. 163-193.

Harrington, P.K. 1985: Formation of Pockmarks by Pore-Water Escape. Geo-Marine Letters 5, 193-197. https://doi.org/10.1007/BF02281638.

Hjelstuen, B.O., Haflidason, H., Sejrup, H.P. \& Lyså, A. 2009: Sedimentary processes and depositional environments in glaciated fjord systems - Evidence from Nordfjord, Norway. Marine Geology 258, 88-99. https://doi.org/10.1016/j.margeo.2008.11.010.

Hjelstuen, B.O., Kjennbakken, H., Bleikli, V., Ersland, R.A., Kvilhaug, S., Euler, C. \& Alvheim, S. 2013: Fjord stratigraphy and processes - evidence from the NE Atlantic Fensfjorden system. Journal of quarternary Science 28, 421-432.

Hjelstuen, B.O. \& Brendryen, J. 2014: Submarine Mass Movements and Trigger Mechanisms in Byfjorden, Western Norway. In Krastel, S. et al., (eds.): Submarine Mass Movements and Their Consequences, Advances in Natural and Technological Hazards Research 37, pp. 351-359. https://doi.org/10.1007/978-3-319-00972-8_31.

Kolderup, C.F. \& Kolderup, N.H. 1940: Geology over the Bergen arch system. Bergen museums skrifter 20,137 pp.
Lyså, A., Hjelstuen, B.O. \& Larsen, E. 2010: Fjord fill in high-relief area: rapid deposition influenced by deglaciation dynamic, glacioisostatic rebound and gravitational activity. Boreas 39, 39-55. https://doi.org/10.1111/j.1502-3885.2009.00117.x.

Mangerud, J., Aarseth, I., Hughes, A.L.C., Lohne, Ø.S., Skår, K., Sønstegaard, E. \& Svendsen, J.I. 2016: A major re-growth of the Scandinavian Ice Sheet in western Norway during Allerød-Younger Dryas. Quaternary Science Reviews 132, 175-205. https://doi.org/10.1016/j.quascirev.2015.11.013.

Morgan, E.C., Vanneste, M., Longva, O., Lecomte, I., McAdoo, B. \& Baise, L. 2010: Evaluating Gas-generated pore pressure with seismic reflection data in a landslide-prone area: An Example from Finneidfjord, Norway. In Mosher, D.C., Shipp, R.C., Moscardelli, L, et al. (eds.): Submarine Mass Movements and Their Consequences, Advances in Natural and Technological Hazard Research 28, Springer Dordrecht Heidelberg, London New York, pp. 399-410. https://doi.org/10.1007/978-90-481-3071-9_33.

Muñiz, F., Belaústegui, Z., Cárcamo, C., Domènech, R. \& Martinell, J. 2015: Cruziana- and Rusophycus-like traces of recent Sparidae fish in the estuary of the Piedras River (Lepe, Huelva, SW Spain). Palaeogeography, Palaeoclimatology, Palaeoecology 439, 176-183. https://doi.org/10.1016/j.palaeo.2015.03.017.

Plassen, L. \& Vorren, T.O. 2003: Fluid flow features in fjord-fill deposits, Ullsfjord, North Norway. Norwegian Journal of Geology 83, 37-42.

Rogers, J.N., Kelley, J.T., Belknap, D.F. Gontz, A. \& Barnhardt, W.A. 2006: Shallow water pockmark formation in temperate estuaries: A consideration of origins in the western gulf of Maine with special focus on Belfast Bay. Marine Geology 225, 45-62. https://doi.org/10.1016/j.margeo.2005.07.011.

Stoker, M., Bradwell, T., Wilson, C., Harper, C., Smith, D. \& Brett, C. 2006: Pristine fjord landsystem revealed on the sea bed in the Summer Isles region, NW Scotland. Scottish Journal of Geology 42, 89-99. https://doi.org/10.1144/sgg42020089.

Wennberg, O. \& Milnes, A. 1994: Interpretation of kinematic indicators along the northeastern margin of the Bergen Arc system: a preliminary field study. Norwegian Journal of Geology 74, 166-173. 